\title{
The Fine Structure of Bacillus finitimus and Bacillus thuringiensis Spores with Special Reference to the Location of Crystal Antigen
}

\author{
By J. A. SHORT, P. D. WALKER AND R. O. THOMSON \\ Department of Bacteriology, Wellcome Research Laboratories, Beckenham, Kent
}

AND H. J. SOMERVILLE

Shell Research Ltd, Woodstock Laboratory, Sittingbourne, Kent

(Received I8 February 1974; revised 22 April 1974)

\begin{abstract}
SUMMARY
The ultrastructure of Bacillus finitimus and B. thuringiensis spores has been examined using the freeze-etching technique. Labelled antibodies have been used in an attempt to locate crystal antigen in the spores of $B$.thuringiensis, which have a more complex structure than those of $B$. finitimus. The results of morphological studies and the use of labelled antibodies to stain sections of sporulating cells of $B$. thuringiensis suggest a relationship between crystal protein and the sporecoat of the organism. The different aspects of ultrastructure and their relation to crystal structure and formation are discussed.
\end{abstract}

\section{INTRODUCTION}

Several spore forming bacteria form inclusions at the time of sporulation. In B.thuringiensis this has been shown to be a crystalline protein (Labaw, 1964; Holmes \& Monro, 1965) toxic to lepidopterous larvae (Hannay \& Fitz-James, 1955; Angus, 1956). According to Heimpel \& Angus (1958), B. finitimus could be distinguished from $B$. thuringiensis in that, in the former, the inclusion is retained by the spore after sporulation is completed and also it is non-toxic to insect larvae.

However, recent work (Somerville, James, Ruffell \& Norris, 197I) has shown that the inclusion of $B$. finitimus can be separated from the spore and that it is both toxic and structurally similar to that of $B$. thuringiensis. This evidence, along with results of DNA/DNA hybridization studies (Somerville \& Jones, 1972), strongly suggests that B. finitimus is a variety of $\boldsymbol{B}$. thuringiensis, as originally suggested by de Barjac \& Bonnefoi (1962).

Detailed studies on sporulation in $B$. thuringiensis were carried out, using the light microscope, by Young \& Fitz-James (1959). Fitz-James (I962) concluded from an electron microscopic study that the inclusion was associated with the forespore membrane during early stages of its formation and was completed in the sporangial cytoplasm. More recently a clear association has been demonstrated between immature crystals and the developing exosporium (Somerville \& James, 1970; Somerville, 1971) and it was suggested that the subunits are synthesized and the crystals assembled on this membrane.

It has also been established (Delafield, Somerville \& Rittenberg, 1968; Somerville, Delafield \& Rittenberg, I968, 1970; Lecadet, Chevrier \& Dedonder, 1972) that the crystal protein is immunologically and biochemically similar to a protein fraction that can be removed from 
spores of $B$. thuringiensis and some other sporeformers by extraction with reagents, such as $\mathrm{O} \cdot \mathrm{I} \mathrm{M}-\mathrm{NaOH}$, which dissolve the crystal.

The present work was undertaken to investigate the ultrastructural morphology of spores of $\boldsymbol{B}$. finitimus and $\boldsymbol{B}$. thuringiensis and to obtain information on the relationship between the crystalline inclusion and the spore.

\section{METHODS}

Organisms. The strains of $\boldsymbol{B}$. thuringiensis used were serotypes I (var. tolworth) and 2 (var. finitimus) and these were maintained as described by Somerville \& Jones (1972). The serotype 2 strain is described throughout this paper as $\boldsymbol{B}$. finitimus.

Preparation of spores. Spores were prepared as previously described by Delafield et al. (1968).

Extraction of spores. Spores were extracted with buffer (Ellis, I96I) containing the following (all at $0.05 \mathrm{M}$ final concentration): $\mathrm{Na}_{2} \mathrm{CO}_{3}, 2$ amino-2-methyl I,3-propane diol, citric acid, and 2-mercaptoethanol. The $\mathrm{pH}$ was adjusted to $10 \cdot 2$ with $\mathrm{NaOH}$. A lyophilized suspension of spores (100 mg) was incubated in $5 \mathrm{ml}$ of this buffer for $2 \mathrm{~h}$ and then centrifuged $(5000 \mathrm{~g}, 10 \mathrm{~min})$. The spores were washed twice in the buffer and then at least four times with distilled water. In some cases spores were extracted with $0 . \mathrm{I} \mathrm{M}-\mathrm{NaOH}$, or with $8 \mathrm{M}$-urea containing $\mathrm{I} \%(\mathrm{w} / \mathrm{v})$ 2-mercaptoethanol, $\mathrm{pH} 8.5$, using the same procedure.

Preparation of antisera. Crystal solutions for injection into animals were prepared as follows. Crystals (greater than $99.95 \%$ pure relative to spores on a numerical count) were prepared as described by Delafield et al. (1968). The crystals were dissolved in buffer at pH 10.2 and the clear solution dialysed against $0.015 \mathrm{M}-\mathrm{NaHCO}_{3}$. Rabbits were selected and antiserum prepared as described previously (Somerville, 197I). Each batch of antiserum was tested for specificity using double diffusion in agar against (i) crystal solution, and (ii) an extract prepared by breaking spores $(25 \mathrm{mg} / \mathrm{ml}$ in $0.05 \mathrm{M}$-phosphate buffer, $\mathrm{pH} 7 \cdot 0)$ in a Braun disintegrator (Somerville, I97I). Only those antisera which did not react with the spore extract were used.

Ferritin labelling. Antisera prepared and tested as described above were conjugated with ferritin (Wellcome Research Laboratories) using the method of Singer \& Schick (196I). Spore-crystal mixtures and disintegrated spores of $B$. thuringiensis were stained as previously described by Walker, Baillie, Thomson \& Batty (1966).

Peroxidase labelling. Mixtures of well-washed spores and crystals of $B$. thuringiensis were fixed for $4 \mathrm{~h}$ at $4{ }^{\circ} \mathrm{C}$ in $2.5 \%$ phosphate buffered glutaraldehyde $\mathrm{pH} 7.2$ and embedded in glycol methacrylate as described by Granboulan \& Leduc (1967).

Crystal antigen was identified in ultra-thin sections using the technique developed by Sternberger, Hardy, Cuculis \& Meyer (1970) employing the use of unlabelled antibody and the soluble peroxidase-antiperoxidase complex (PAP) (Wellcome Research Laboratories). The immunochemical staining procedure was essentially the same as that previously described by Moriarty \& Halmi (1972). Controls were included in which the antiserum was substituted with normal rabbit serum or one of the stain components, i.e. antiserum, antirabbit IgG, PAP or DAB (3,3'-diaminobenzidine) was omitted.

Electron microscopy. Spore suspensions in distilled water were freeze-etched using a Balzer $360 \mathrm{M}$ freeze-etching apparatus as described by Moor, Muhlethaler, Waldner \& FreyWyssling (196I). The specimen temperature was $-100{ }^{\circ} \mathrm{C}$ and the etching time $\mathrm{I}$ min. The shadowing angle was approximately $33^{\circ}$ and the vacuum obtained in the system $10^{-6} \mathrm{mmHg}$. The platinum/carbon replicas were cleaned with $70 \%$ sulphuric acid for $\mathrm{I} h$ followed by 
sodium hypochlorite (Io to $14 \%, w / v$, available chlorine) for $\mathrm{I} h$. This was followed by three washes in distilled water each of 15 min duration. Cleaned replicas were picked up on uncoated 400 mesh copper grids.

For negative staining, preparations were suspended in $0.05 \mathrm{M}$-phosphate containing $0.01 \%$ (w/v) Triton X-100 (BDH), pH 7.0, dried on 200 mesh Formvar-coated copper grids and stained with phosphotungstic acid. Sections were cut on an L.K.B. ultramicrotome, using glass knives, and collected on 200 mesh Formvar-coated grids. All specimens were examined in a Philips EM200 or EM300 electron microscope at $60 \mathrm{kV}$.

\section{RESULTS}

\section{Freeze-etching}

Bacillus finitimus. Initial observations on spores which had not been fractured (Fig. I) demonstrated a granular exterior on which there was no discernable regular orientation. This was taken as the outer surface of the exosporium. In many cases a crystalline inclusion was visible through this layer and structure apparent in it. Fracturing of the exosporial surface revealed two types of structural layers. The first type were pitted (Fig. 2) and sometimes more than one layer was seen (Fig. 3). The pits were 4.5 to $5.0 \mathrm{~nm}$ in diameter and arranged hexagonally with a row-to-row spacing of 7 to $8 \mathrm{~nm}$. The second type consisted of regularly arranged globular granules, 4.5 to $5 \mathrm{~nm}$ in diameter (Fig. 4). These were also arranged hexagonally with a similar row-to-row spacing. Both layers were taken to be parts of the sporecoat, based on the depth of fracture and the similarity to structures seen previously in $B$. cereus (Holt \& Leadbetter, 1969). Where the crystal inclusion as well as the exosporium had been fractured (Fig. 5) the granular layer of the sporecoat was apparently continuous with the inclusion. Fibrous connexions between the underside of the exosporium and the sporecoat were evident (Figs. 2 and 3).

Bacillus thuringiensis. The spores of $B$. thuringiensis also showed a granular outer surface (Fig. 6). However, they differed from $B$. finitimus spores in that the outer surfaces of most of the spores were pitted or punctured by holes. Upon fracturing, a layer of hexagonally arrayed spherical particles 7 to $7.5 \mathrm{~nm}$ apart (Fig. 7) was revealed immediately under the granular exterior, though it was difficult to obtain fractures that exposed this layer. These granules could not be distinguished from those observed in spores of $B$. finitimus or in deeper etches of $B$. thuringiensis.

The more common fracture face obtained was much deeper and revealed three structural layers. Two of these, the deepest, were like the pitted and granular layers already described for B. finitimus (Fig. 8) and had identical spacings to these layers $(7.0$ to $8.0 \mathrm{~nm}$ ). The third layer consisted of very small granules $(2.5$ to $3.0 \mathrm{~nm}$ diam), again in a regular hexagonal arrangement (Fig. 9); the row-to-row spacing was 4.5 to $5.0 \mathrm{~nm}$. The layer could be seen as a continuous sheet or as an overlapping 'leaf-like' structure ( $\overline{\text { Fig. }}$ Io). Numerous fibrous connexions between layers were common (Fig. II), which sometimes appeared to pass through the fine granular layer and connect the underside of the exosporium to the deeper pitted and granular layers.

Extracted spores. Successful freeze-etched preparations of spores extracted by the various procedures described proved very difficult to obtain. We were, however, able to show that the fine granular layer in $\boldsymbol{B}$. thuringiensis remained after extraction and the granular outer surface of the exosporium did not appear to be disturbed. However, neither regular pits or granules could be recognized in the deeper layers. 

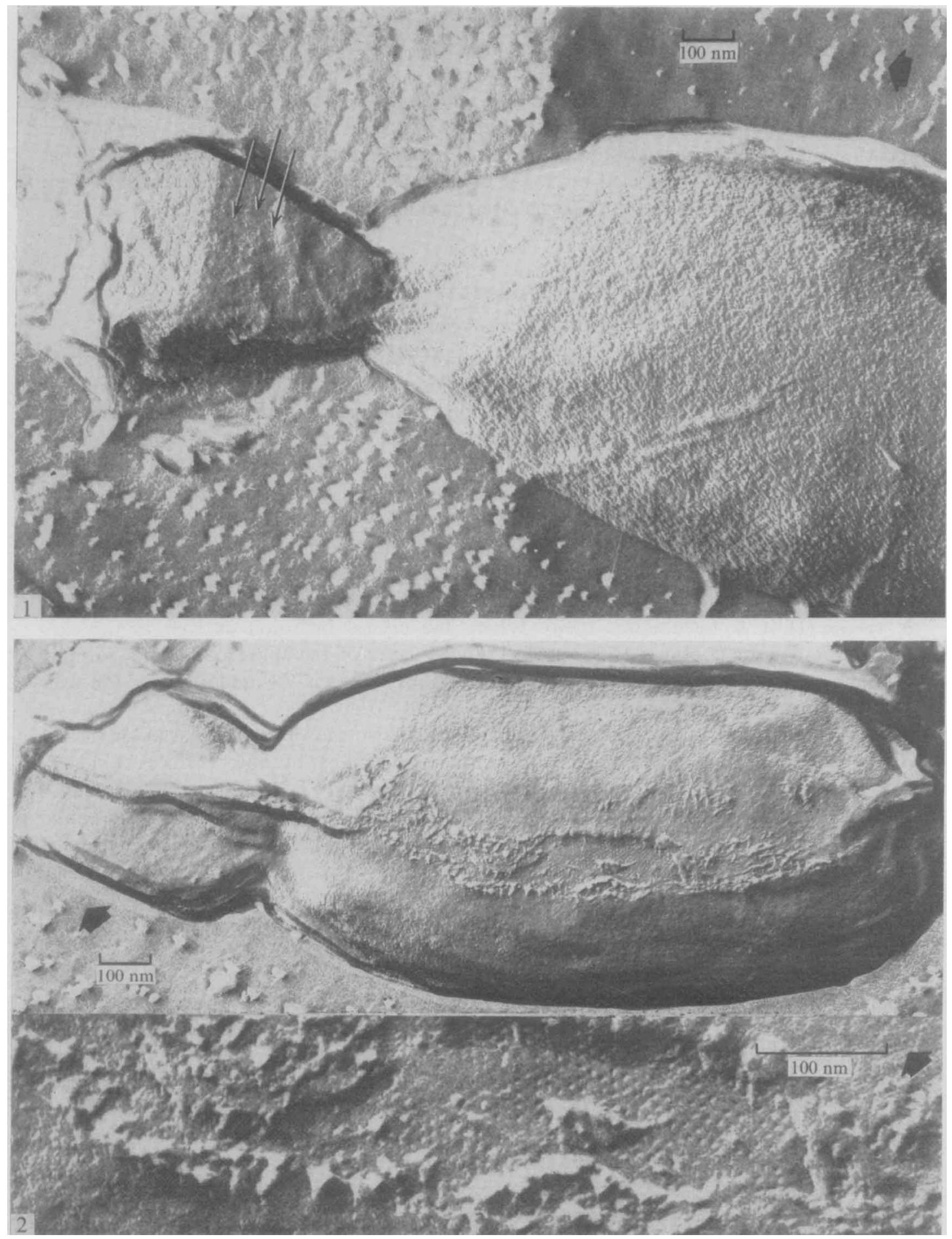

Fig. I. Freeze-etched unfractured spore of B. finitimus showing the granular outer surface of the exosporium. A crystal inclusion is visible through the exosporium (thin arrows).

Fig. 2. Freeze-etched fractured spore of B. finitimus showing deeper pitted layer of the sporecoat. Inset shows higher magnification.

Wide arrows, shadow direction. 

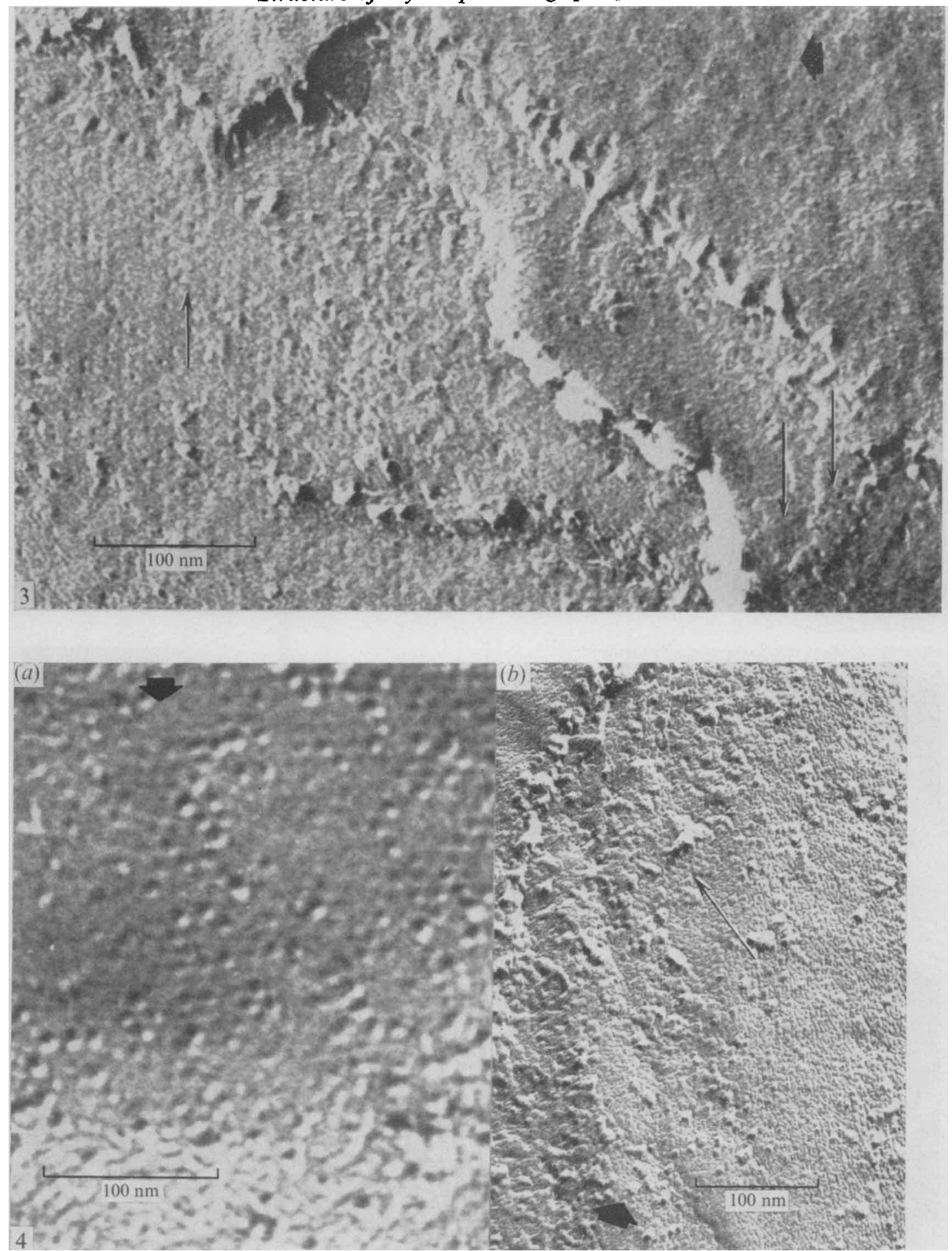

Fig. 3. This is similar to Fig. 2, showing more than one pitted layer (thin arrows). Note the fibrous connexions between the under surface of the exosporium and the sporecoat.

Fig. 4. Freeze-etched $B$. finitinus spore showing the regularly arrayed globular granules (thin arrow). Magnification is higher in $(b)$ than $(a)$.

Wide arrows, shadow direction. 

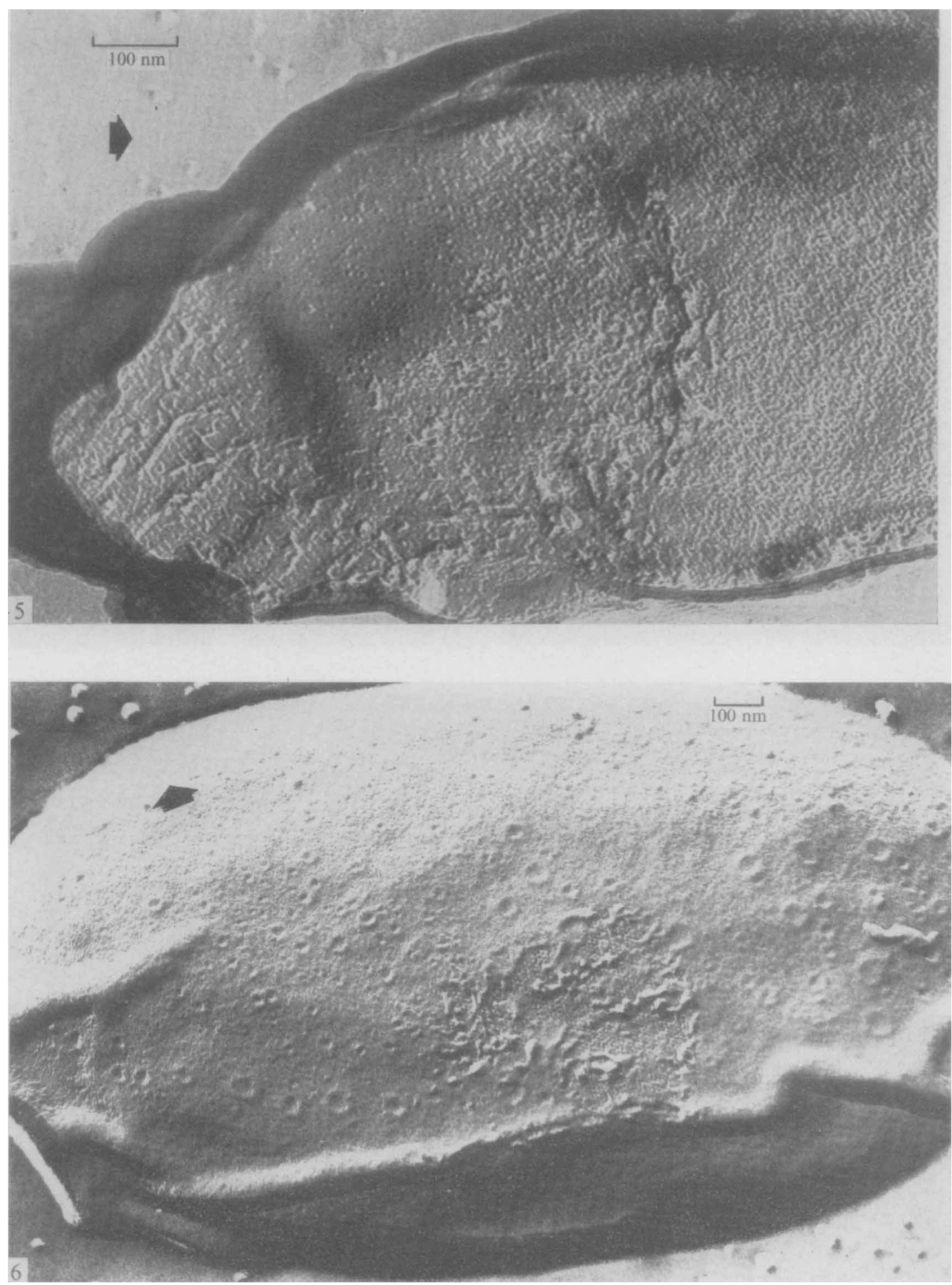

Fig. 5. Freeze-etched fractured spore and crystal inclusion of B. finitimus, showing continuity between the globular granules of the sporecoat and the inclusion.

Fig. 6. Freeze-etched fractured spore of B. thuringiensis, showing the pits and holes in the outer granular surface of the exosporium, and the hexagonally-arrayed spherical particles directly under the granular exterior.

Wide arrows, shadow direction. 

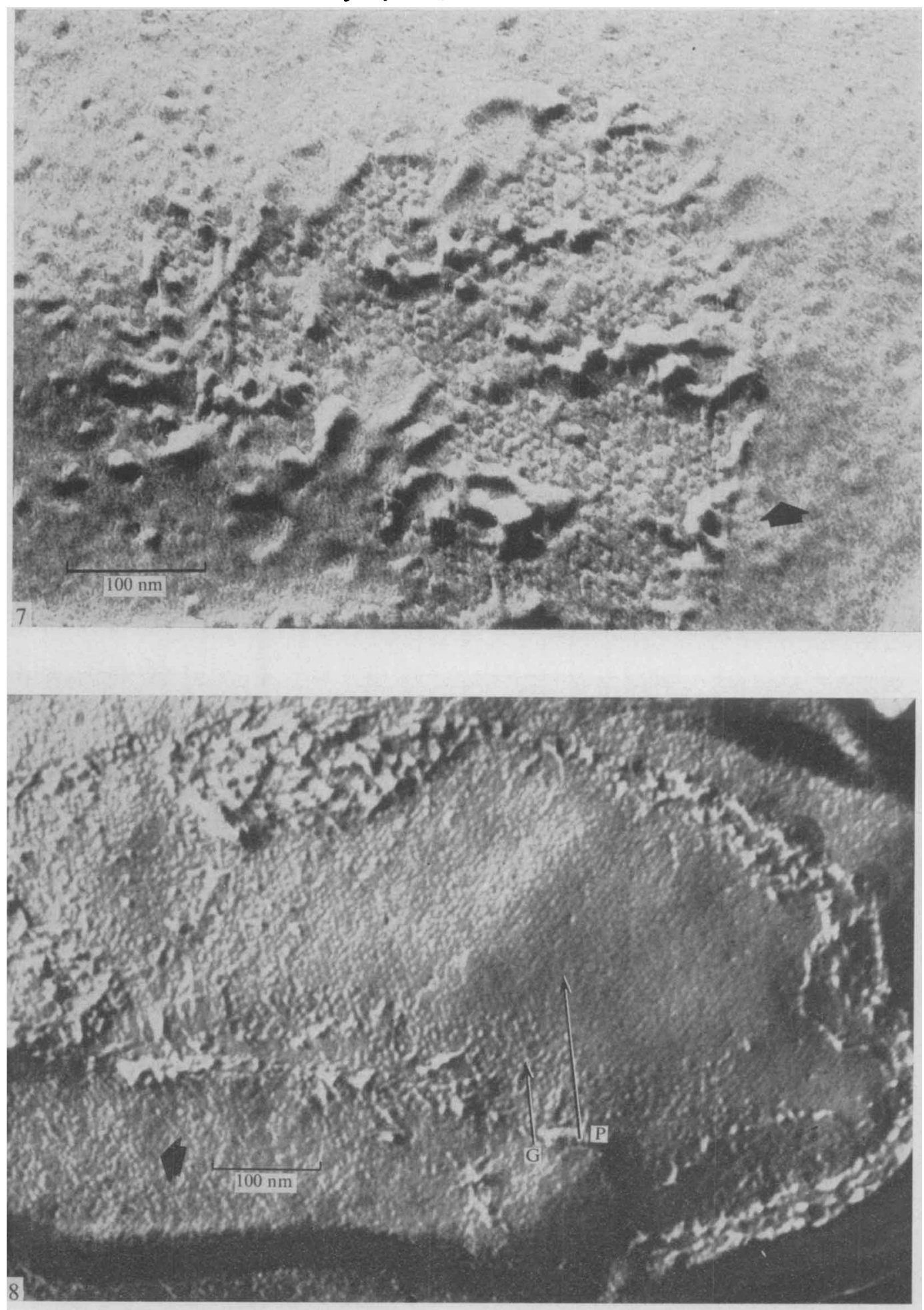

Fig. 7. High-power micrograph of Fig. 6, showing details of hexagonally-arranged spherical particles.

Fig. 8. Freeze-etched spore of $B$. thuringiensis, showing alternate layer of granules $(G)$ and pits $(P)$. Wide arrows, shadow direction. 

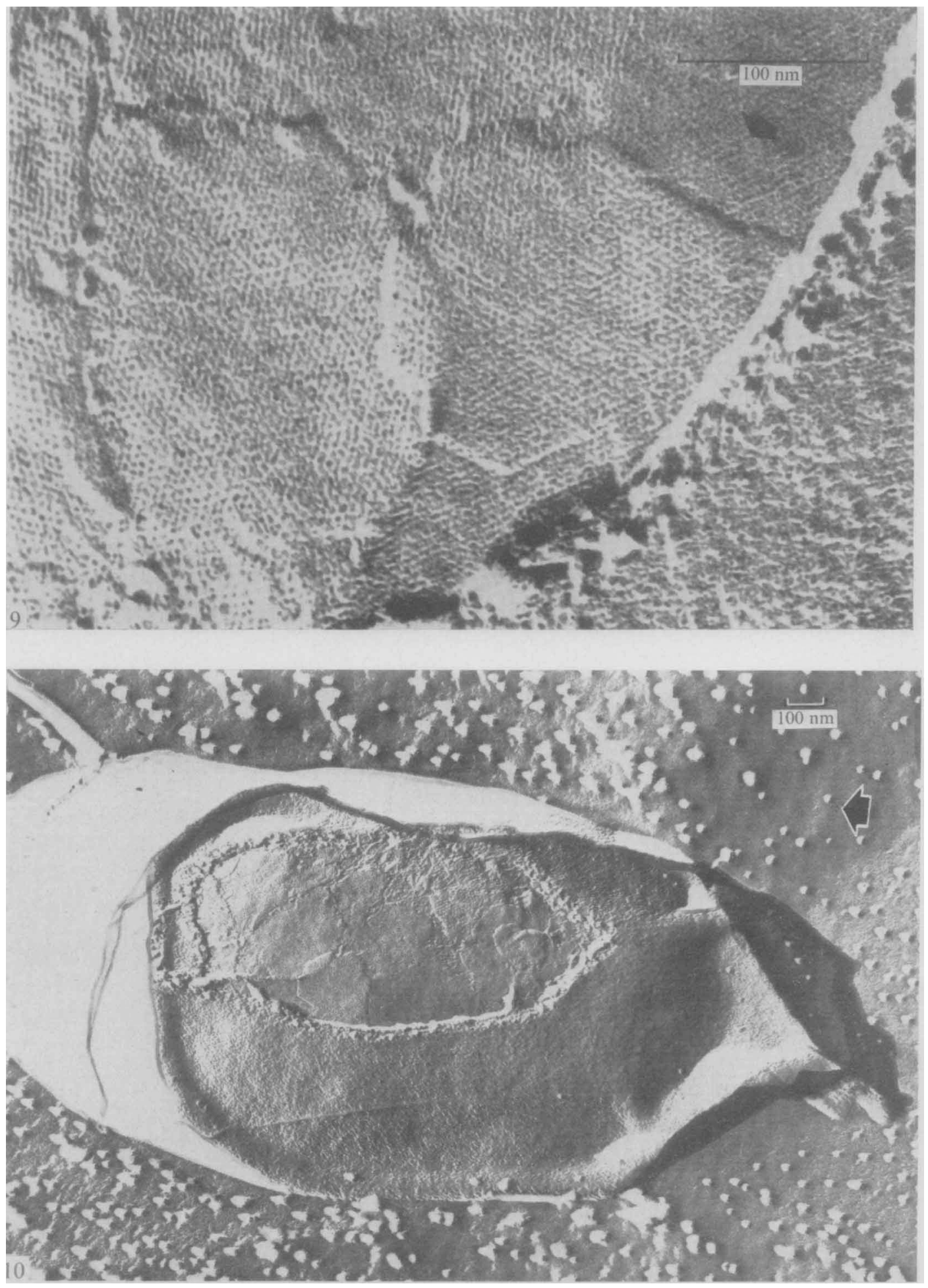

Fig. 9. High-power micrograph of $B$. thuringiensis, showing small hexagonally-arranged granules.

Fig. Io. Freeze-etched spore of B. thuringiensis, showing the overlapping 'leaf-like' structure of the small granular layer.

Wide arrows, shadow direction. 

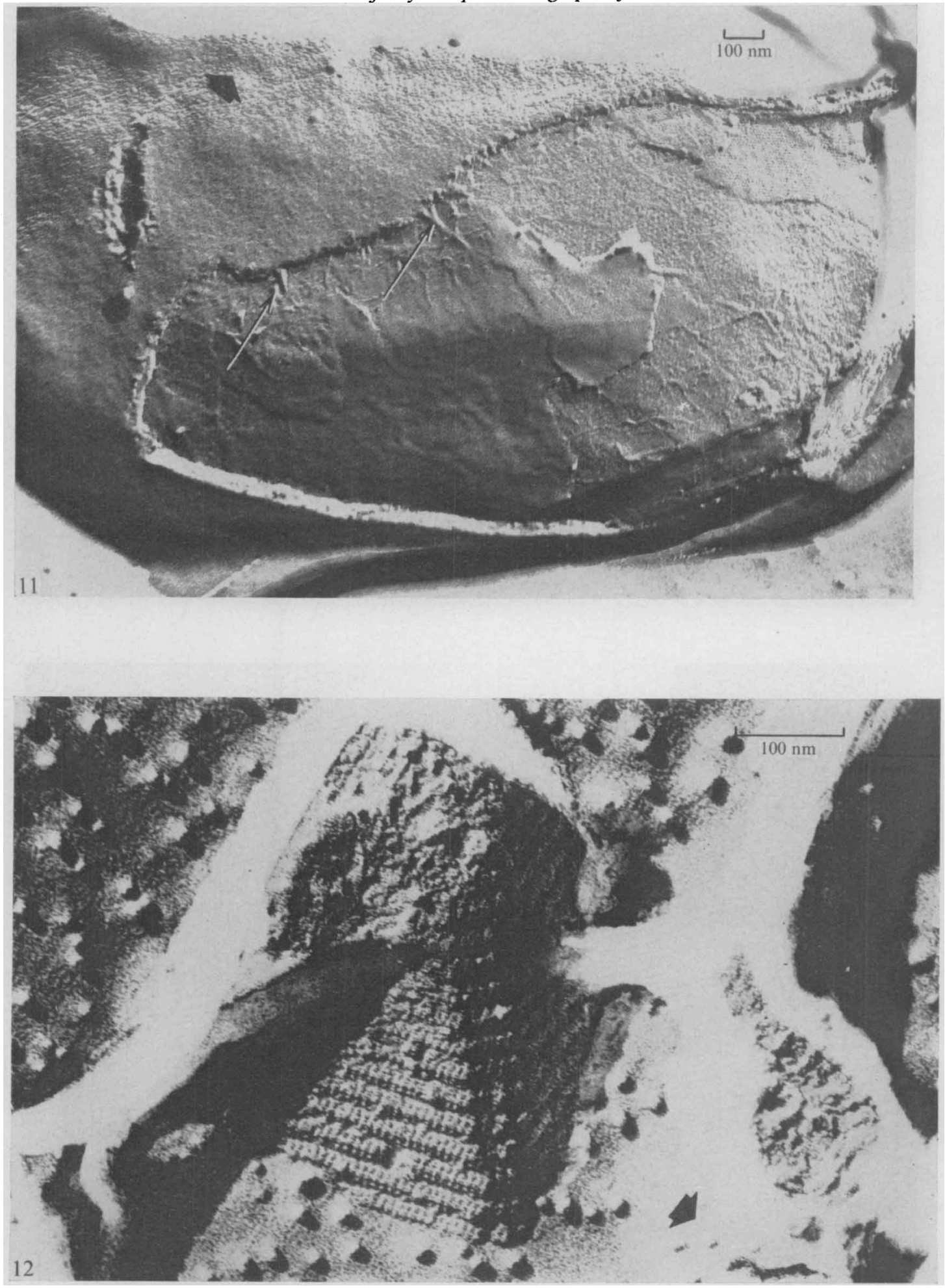

Fig. II. Freeze-etched spore of B. thuringiensis, showing thick fibrous connexions between the different layers (thin arrows).

Fig. I2. Freeze-etched preparation of a crystal inclusion from B. thuringiensis.

Wide arrows. shadow direction. 

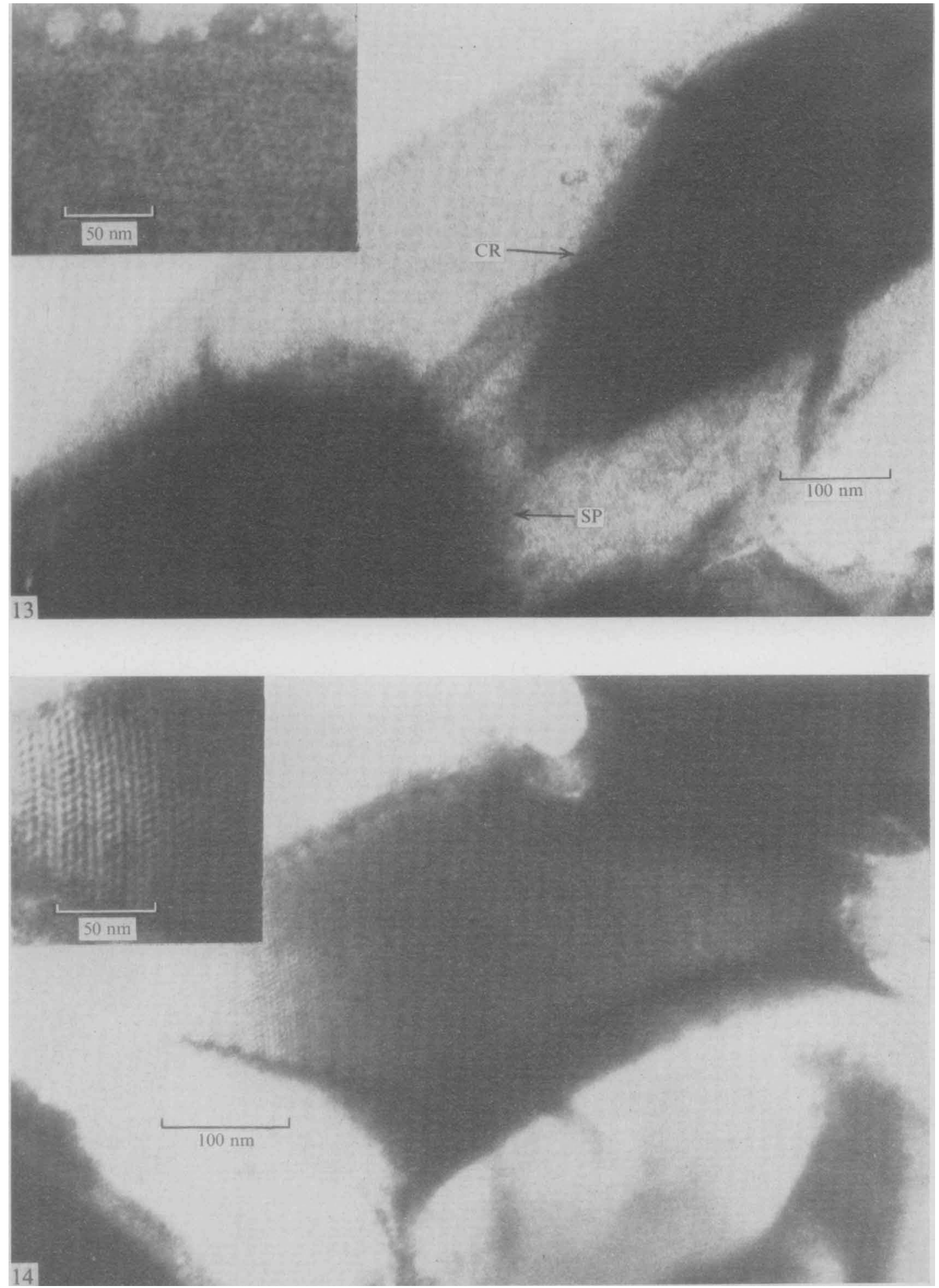

Fig. I3. Negatively stained spore (SP) and crystal (CR) of B. thuringiensis var. finitimus showing details of exosporium structure. Inset shows higher magnification.

Fig. I4. Negatively stained crystal of $B$. thuringiensis var. finitimus showing details of crystal structure. Inset shows higher magnification. 

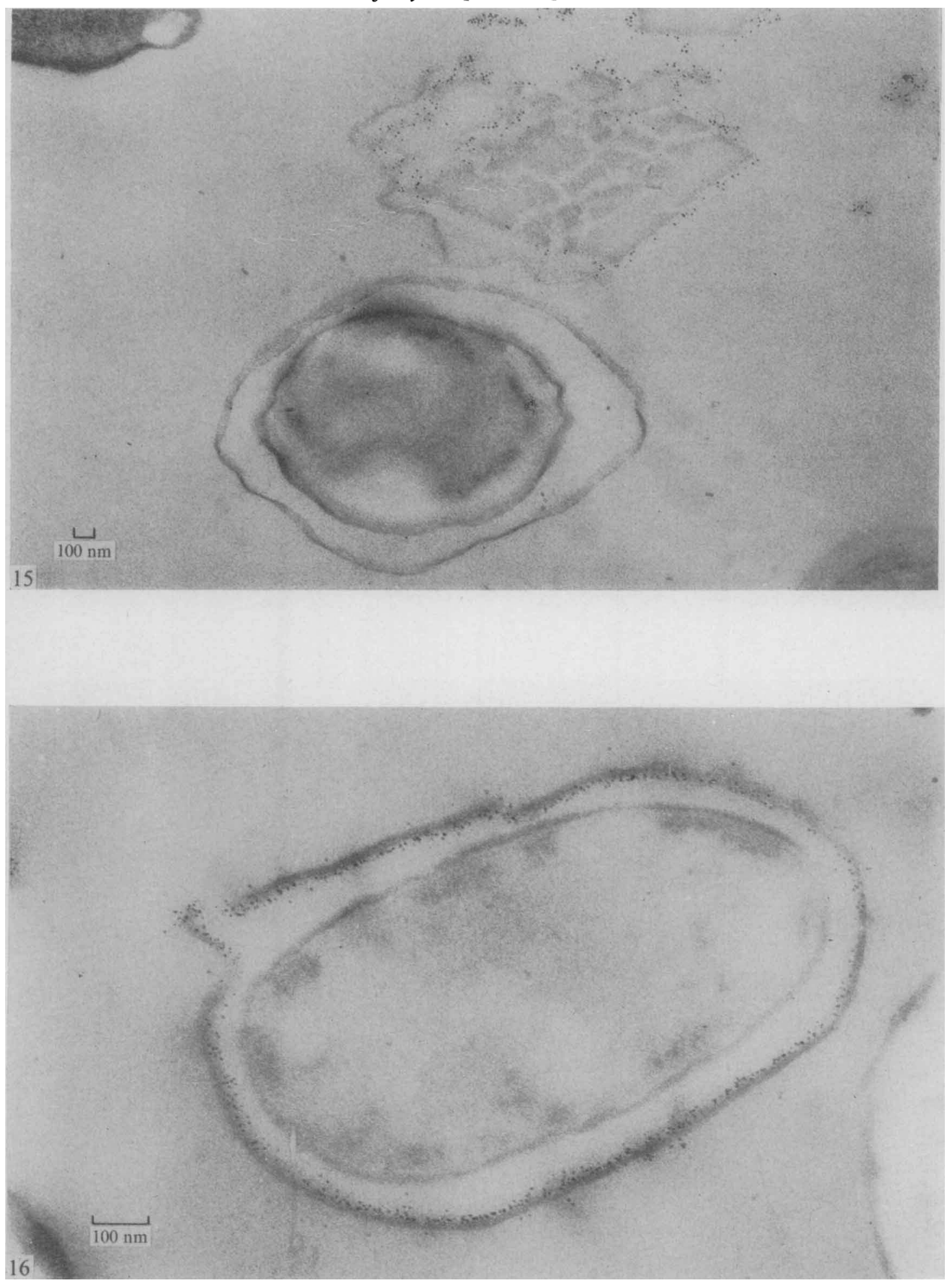

Fig. 15. Ultra-thin section of $B$. thuringiensis intact spore and crystal, showing specific ferritin labelling of the crystal.

Fig. 16. Ultra-thin section of a disintegrated spore of $B$. thuringiensis, showing specific ferritin laheiling on the inner aspects of the sporecoat. 

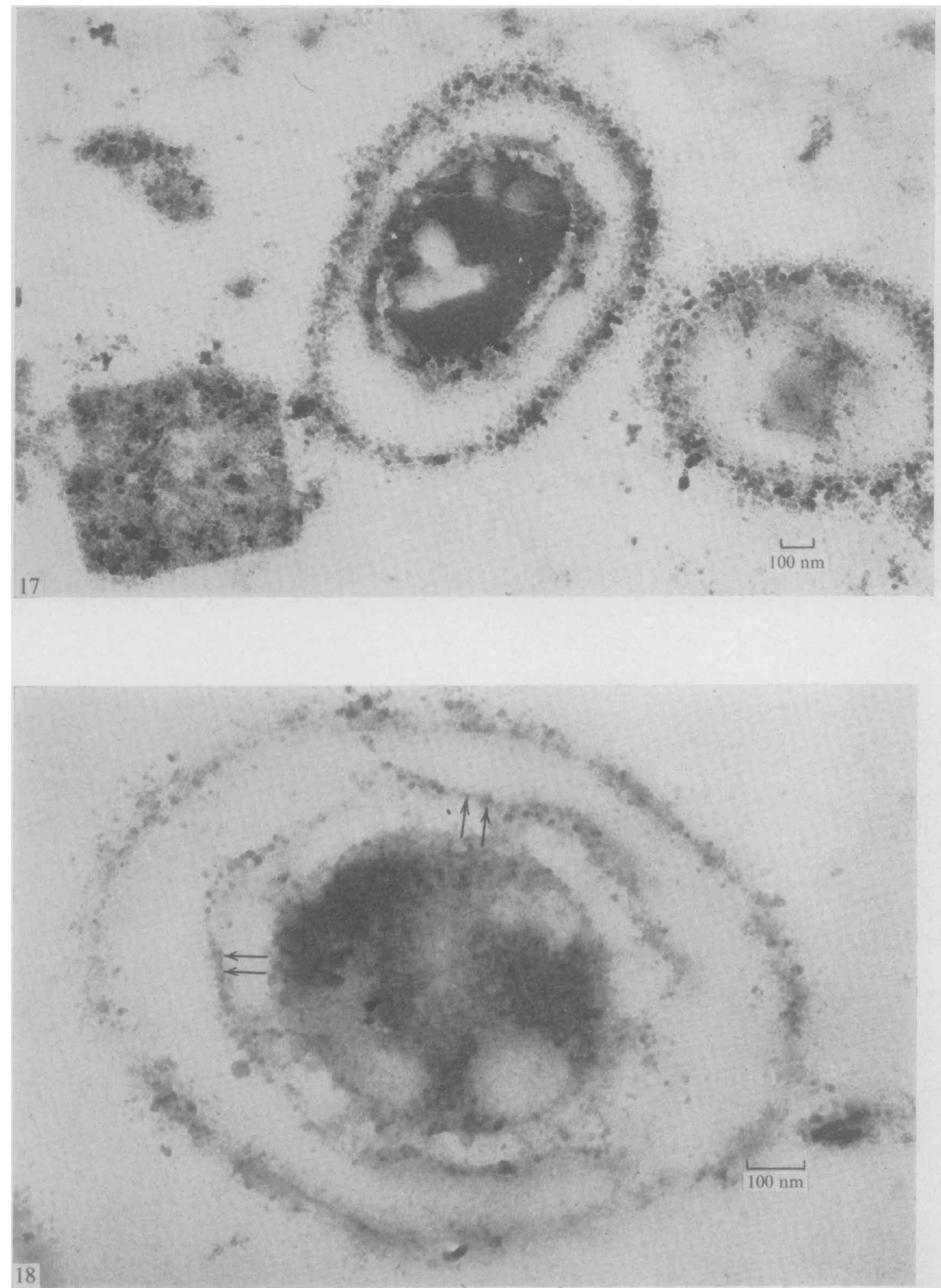

Fig. 17. Ultra-thin sections of spores and crystals of B. thuringiensis stained with peroxidaseantiperoxidase complex, showing staining of exosporium and crystal.

Fig. I 8. Similarly-stained section to Fig. 17, showing staining of exosporium and sporecoat (arrows). 
Crystal suspension. A frozen-etched preparation of $B$. thuringiensis crystals demonstrated the classical pyramidal structure (Norris, 1971) (Fig. I2). Viewing of crystal subunits was possible using this technique.

\section{Negative staining}

Structure observed by negative staining of spores and crystals has been reported briefly (Somerville et al. 197I). Negative staining of whole spores reveals detailed structure in the exosporium at high magnification. In both $B$. finitimus and $B$. thuringiensis a clear hexagonal pattern was observed (Fig. 13) with a row-to-row spacing of 6.0 to $7.0 \mathrm{~nm}$. There is no evidence that this is due to Moiré patterns (Beaman, Pankratz \& Gerhardt, 1971). Purified crystals showed detailed structure near the apex (Fig. I4); at higher magnification it could be seen that this structure involved a repeating sequence of three rows separated by equal spaces, followed by one row separated on either side by a slightly greater space. It is possible that these represent 'steps' on the outer surface of the crystal and the structure is remarkably similar to that revealed by freeze-etching of crystals (Fig. 12; Norris, 1969). The particles evident in the three equally-spaced rows were arranged hexagonally with a row-to-row spacing of approximately $7.5 \mathrm{~nm}$. This spacing correlates well with similar measurements from freeze-etched preparations.

\section{Ferritin labelling}

In $B$. thuringiensis it can be seen that ferritin-labelled antibody to crystal protein is specifically located on crystals, whilst the intact spore surface (i.e. exosporium) shows no labelling (Fig. 15). Disintegrated spores (Fig. 16) show a clear labelling of the inner surfaces of the sporecoat. During disintegration the exosporium is stripped off and largely destroyed.

\section{Peroxidase labelling}

After treatment of ultra-thin sections with peroxidase-antiperoxidase complex, crystals of B.thuringiensis were specifically labelled with deposits of DAB polymer (Fig. I7). In addition, deposits were also located along the exosporium and on the inner layers of the sporecoat (Fig. I8).

\section{DISCUSSION}

The morphological changes occurring during sporulation in B. finitimus and B. thuringiensis closely resemble those occurring in $B$. cereus and other bacillus species (Young \& Fitz-James, 1959; Fitz-James, 1962, 1965; Ellar \& Lundgren, 1966; Leadbetter \& Holt, 1968; Somerville, 197I). Similarities between the structure of the outer surface of the exosporium of these species and $B$. cereus is also evident from freeze-etching. The presence of the deeper regularly-arrayed layer in the exosporium of $B$. thuringiensis correlates well with observations made by Gerhardt \& Ribi (1964) on negatively stained preparations of bacillus exosporia. This layer was not seen in B. finitimus. The pits and holes on the exosporium surface of $B$. thuringiensis could be an artefact but their regular occurrence and definite morphological appearance would, in our opinion, make this improbable. These openings could represent the pores in the exosporial fabric that have been suggested by Gerhardt \& Black (I96I) as a result of permeability studies on exosporium-covered spores. It is possible that in $B$. thuringiensis these pores allow crystal protein to pass out through the exosporium as sporulation proceeds.

Delafield et al. (1968) reported that biochemically and immunologically a portion of spore protein closely resembled the crystal protein in B. thuringiensis. A close association is 


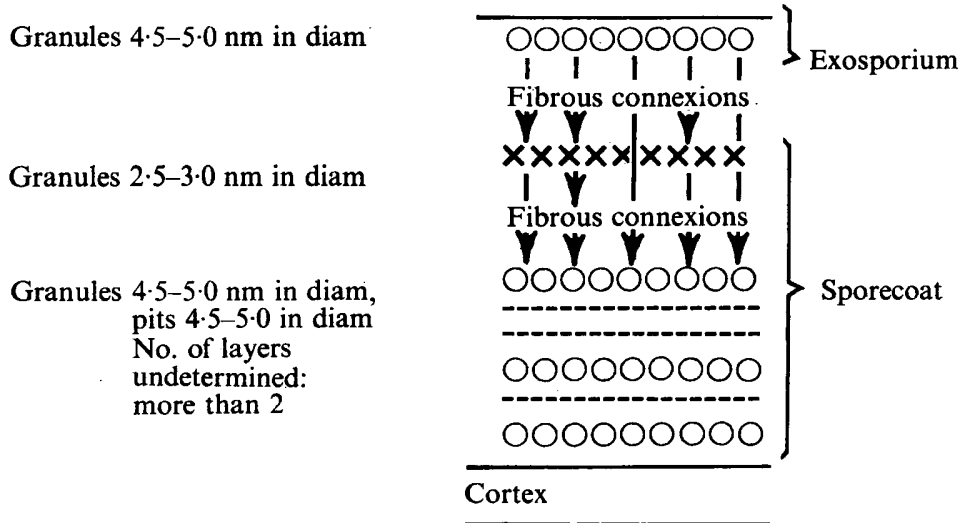

Fig. 19. Model illustrating proposed structure of $\boldsymbol{B}$. thuringiensis spores.

Granules $4 \cdot 5-5 \cdot 0 \mathrm{~nm}$ in diam, pits 4.5-5.0 $\mathrm{nm}$ in diam No. of layers undetermined more than 2

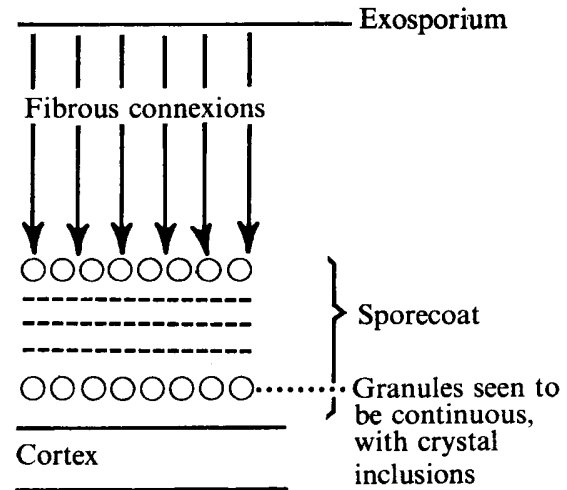

Fig. 20. Model illustrating proposed structure of $\boldsymbol{B}$. finitimus spores.

observed between the developing crystal and the exosporium (Somerville \& James, 1970; Somerville, I97I). Somerville et al. (I97I) concluded that a similar association occurred during inclusion formation in $\boldsymbol{B}$. finitimus, although in this case other observations suggested that a continuity of the inclusion with the developing sporecoat could not be excluded. Such an association appears in some freeze-etched preparations of B. finitimus (Fig. 5) where a continuity between the sporecoat and developing inclusion is seen.

The dimensions and orientation of the sporecoat pitted layers in both types of spores are the same as those already described in deep-etched preparations of B. cereus (Holt \& Leadbetter, I969). It is probable that the granules fit into these pits and the sporecoat is composed of several alternate pitted and granular layers. The fine granular layer observed between the outer surface of the exosporium and the deeper layers of the sporecoat in B. thuringiensis probably represents an outer sporecoat layer. A similarly constructed layer has been demonstrated in Clostridium sporogenes (Short \& Walker, 197I) and also in C. botulinum type E (Walker and Short, unpublished observations). There is undoubtedly some difficulty in terminology relating to these layers and, indeed, many workers prefer to regard the exosporium as the outer surface of the sporecoat although spatially separate. If the exosporium and sporecoat are considered together then the combined structure in $B$. thuringiensis is more complex than in B. finitimus (Figs. 19 and 20). In B. thuringiensis there are two addi- 
tional layers: the regular granules observed immediately under the outer exosporial surface, and the fine granular layer. Bearing in mind the resolution of the freeze-etching technique it is difficult to be certain whether measurements on the dimensions of the latter layer represent a true resolution or a decoration effect. There is, however, clearly an additional layer, either differently constructed or having different constituents from the other layers observed. As crystal protein of $\boldsymbol{B}$. finitimus is confined within the exosporium it is possible that protein which would normally have been used in assembling the sporecoat is incorporated into the crystal. On the other hand, in $\boldsymbol{B}$. thuringiensis the crystal is assembled outside the exosporium although in close association with it, and it is possible that sporecoat proteins produced during sporulation escape through the pits in the exosporium to be re-assembled on a template on the outer surface.

The regular granules observed immediately under the exosporial outer covering could represent crystal protein trapped under the exosporium during spore maturation. The antigenic evidence supports this hypothesis. Using ferritin-labelled antibodies to stain mixtures of crystals and disintegrated spores, the evidence suggests that in $B$. thuringiensis antigens common to the crystal and the deeper layers of the sporecoat are present. Additional evidence supporting the relationship between the deeper layers of the sporecoat and the crystal protein is the failure to demonstrate pits and granules in freeze-etches of the sporecoat of spores extracted with 2-mercaptoethanol, which is known to extract material antigenically similar to the crystal. However, there is no antigenic evidence for a relationship between crystal protein of $B$. thuringiensis and the outer surface of the exosporium.

The results obtained on ultra-thin sections using the peroxidase-antiperoxidase technique, however, indicate that the exosporium contains antigens common to crystal protein. Because of the diffuse nature of the reaction product, it is difficult to locate the antigens precisely with this technique, and we therefore prefer to interpret staining of the exosporium by antibodies to the crystal as being due to reaction with the inner layers of the exosporium, while accepting the evidence of ferritin-labelled antibody as indicating a lack of reaction with the outer surface. Staining of the sporecoat using this technique confirms the results with ferritin-labelled antibody.

\section{REFERENCES}

ANGUS, T. A. (1956). Association of toxicity with protein-crystalline inclusions in Bacillus sotto IsLiwata. Canadian Journal of Microbiology 2, 416-425.

Beaman, T. C., Pankratz, H. S. \& Gerhardt, P. (I97I). Paracrystalline sheets reaggregated from solubilized exosporium of Bacillus cereus. Journal of Bacteriology 107, 320-324.

DE BARJAC, H. \& Bonnefor, A. (I962). Essai de classification biochemique et sérologique de 24 souches de Bacillus de type thuringiensis. Entomophaga 7, 5-17.

Delafield, F. P., Somerville, H. J. \& RittenberG, S. C. (1968). Immunological homology between crystal and spore protein of Bacillus thuringiensis. Journal of Bacteriology 96, 713-720.

Ellar, D. J. \& LundGren, D. G. (I966). Fine structure of sporulation in Bacillus cereus grown in chemically defined medium. Journal of Bacteriology 92, 1748-1764.

Ellis, D. A. (1961). A new universal buffer. Nature, London 192, 1099.

FItZ-JAMES, P. C. (I962). The initial formation of parasporal inclusions in bacilli. Proceedings $V$ International Congress of Electron Microscopy 2, RR. 10.

Fitz-JAMEs, P. C. (1965). Spore formation in wild and mutant strains of Bacillus cereus and some effects of inhibitors. In Mecanismes de Regulation des Activités Cellulaires chez les Micro-organismes, p. 529. Edited by M. J. C. Senez. Paris: Centre Nationale de la Recherché Scientifique.

Gerhardt, P. \& Black, S. H. (I96I). Permeability of bacterial spores. II. Molecular variables affecting solute permeation. Journal of Bacteriology 82, 750-760.

GerhardT, P. \& RiBi, E. (I964). Ultrastructure of the exosporium enveloping spores of Bacillus cereus. Journal of Bacteriology 88, 1774-1 789. 
Granboulan, P. \& Leduc, E. G. (1967). Ultrastructural cytochemistry of Bacillus subtilis. Journal of Ultrastructure Research 20, II I-126.

Hannay, C. L. \& Fitz-James, P. C. (1955). The protein crystals of Bacillus thuringiensis Berliner. Canadian Journal of Microbiology 1, 694-710.

Heimpel, A. M. \& ANGus, T. A. (1958). The taxonomy of insect pathogens related to Bacillus cereus. Canadian Journal of Microbiology 4, 531-542.

Holmes, K. C. \& MONRo, R. E. (1965). Studies on the structure of parasporal inclusions from Bacillus thuringiensis. Journal of Molecular Biology 14, 572-581.

Holt, S. C. \& LeadbetTeR, E. R. (1969). Comparative ultrastructure of selected aerobic sporeforming bacteria: a freeze etching study. Bacteriological Reviews 33, 346-378.

LABAW, L. W. (1964). The structure of Bacillus thuringiensis Berliner crystals. Journal of Ultrastructure Research 10, 66-75.

LeAdBetTer, E. R. \& Holt, S. C. (I968). The fine structure of Bacillus fastidiosus. Journal of General Microbiology 52, 299-308.

Lecadet, M. M., Chevrier, G. \& Dedonder, R. (1972). Analysis of a protein fraction in the sporecoats of Bacillus thuringiensis. European Journal of Biochemistry 25, 349-358.

Moor, H., Muhlethaler, K., Waldner, H. \& Frey-Wyssling, A. (I96i). A new freezing ultramicrotome. Journal of Biophysical and Biochemical Cytology 10, I-I4.

MoriarTy, G. C. \& HALMi, N. S. (1972). Electron microscopic study of the adrenocorticotropin producing cell with the use of the unlabelled antibody and the soluble peroxidase-antiperoxidase complex. Journal of Histochemistry and Cytochemistry 20, 590-603.

NorRIS, J. R. (1969). Macromolecule synthesis during sporulation of Bacillus thuringiensis. Spores IV, p. 45. Edited by L. L. Campbell. Washington D.C.: American Society for Microbiology.

NoRRIS, J. R. (197I). The protein crystal of Bacillus thuringiensis biosynthesis and physical structure. Microbial Control of Insects and Mites, p. 229. Edited by H. D. Burges and N. W. Hussey. London: Academic Press.

SHORT, J. \& WALKER, P. D. (1971). Structure of bacterial spores as revealed by freeze etching. Spore Research (197I), p. 189. Edited by A. N. Barker, G. W. Gould and J. Wolf. London: Academic Press.

Singer, S. J. \& SCHICK, A. F. (I96I). The properties of specific stains for electron microscopy prepared by the conjugation of antibody molecules with ferritin. Journal of Biophysical and Biochemical Cytology 9 , 519-537.

SOMERVILLE, H. J. (I97I). Formation of the parasporal inclusion of Bacillus thuringiensis. European Journal of Biochemistry 18, 226-237.

Somerville, H. J., Delafield, F. P. \& Rittenberg, S. C. (1968). Biochemical homology between crystal and spore protein of Bacillus thuringiensis. Journal of Bacteriology 96, 721-73I.

Somerville, H. J., Delafield, F. P. \& Rittenberg, S. C. (1970). Urea-mercaptoethanol-soluble protein from spores of Bacillus thuringiensis and other species. Journal of Bacteriology 101, 55 I-560.

SOMERVILLE, H. J. \& JAMES, C. R. (1970). Association of the crystalline inclusion of Bacillus thuringiensis with the exosporium. Journal of Bacteriology 102, 580-583.

Somerville, H. J., JAMES, C. R., RUfFell, R. N. \& NoRRIS, J. R. (1971). The parasporal inclusion of Bacillus finitimus. In Spore Research (197r), p. 193. Edited by A. N. Barker, G. W. Gould and J. Wolf. London: Academic Press.

SOMERVILLE, H. J. \& JoNes, M. L. (1972). DNA competition studies within the Bacillus cereus group of bacilli. Journal of General Microbiology 73, 257-265.

Sternderger, L. A., Hardy, P. H., Jun., Cuculis, J. J. \& Meyer, H. G. (1970). The unlabelled antibody enzyme method of immunohistochemistry. Preparation and properties of soluble antigen-antibody complex (horseradish peroxidase-antihorseradish peroxidase) and its use in identification of spirochetes. Journal of Histochemistry and Cytochemistry $\mathbf{1 8}, 315-333$.

Walker, P. D., Baillie, A., Thomson, R. O. \& BatTy, I. (1966). The use of ferritin labelled antibodies in the location of spore and vegetative antigens of Bacillus cereus. The Journal of Applied Bacteriology 29, $512-518$.

Young, I. E. \& Fitz-JAMES, P. C. (1959). Chemical and morphological studies of bacterial spore formation. II. Spore and parasporal protein formation in Bacillus cereus var. alesti. Journal of Biophysical and Biochemical Cytology 6, 483-498. 